Article

\title{
From Chiapas to Palestine: Historicizing Social Movement Media Before and Beyond the Arab Uprisings
}

\author{
Gretchen King \\ Communication, Arts \& Languages, Lebanese American University, Lebanon; E-Mail: gretchen.king@lau.edu.Ib
}

Submitted: 30 April 2021 | Accepted: 26 October 2021 | Published: 17 December 2021

\begin{abstract}
Critical scholarship investigating media and the Arab uprisings has called for "a return to history." This article argues that researching the contemporary constraints and opportunities of social movement media in the Arab region requires historicizing such practices. Reflecting on the role of media activism within the Arab uprisings necessitates broadening the historical context of social movement media in the Middle East and North Africa (MENA) region by investigating the diversity of media tactics and alternative political economies mobilized to resist the military-industrial communications complex. This article develops a political economy framework to historicize social movement media practices from Chiapas to Palestine and provides a critical reflection on the use of media for revolution before and beyond the Arab uprisings. Learning from the long and global history of revolutionary media struggle is beneficial to media activists and researchers working in the MENA region.
\end{abstract}

\section{Keywords}

Arab uprisings; Chiapas; media activism; MENA; Mexico; revolution; Palestine; political economy of communication; social movement media

\section{Issue}

This article is part of the issue "Ten Years after the Arab Uprisings: Beyond Media and Liberation," edited by Hanan Badr (Gulf University for Science and Technology, Kuwait) and Lena-Maria Möller (Max Planck Institute for Comparative and International Private Law, Germany).

(C) 2021 by the author; licensee Cogitatio (Lisbon, Portugal). This article is licensed under a Creative Commons Attribution 4.0 International License (CC BY).

\section{Introduction}

Research facilitated within social movements drawing on practitioner knowledge complements critical scholarship on media practices and the 2010-2011 Arab uprisings that have called for "a return to history" (Matar, 2012). Armbrust (2012) noted that historical media research is needed specifically in the Middle East and North Africa (or MENA) region to rethink the role of digital platforms, such as satellite and Internet, within a broader and more "social history of media" (p. 170). He recommended a research agenda that documents the adaptation of different media practices over time (such as radio and television broadcasting) to contextualize contemporary uses of so-called new media tools. Matar (2012) agrees, calling for scholars to situate media activism during the uprisings within "ongoing historical processes and conjunctures" (p. 75). She argued, "there is a need to re-historicize, or to re-introduce history, in our discussions of media in order to interrogate the boundaries of how we conceptualize the 'now' and the 'here' without losing sight of their positionality in specific historical formations" (p. 78). Both Armbrust and Matar's emphasis on knowing history to understand the present and think about the future is an important lesson for scholars, journalists, and media activists working in the Arab region and beyond.

This article argues that researching the contemporary constraints and opportunities for social movement media in the Arab region requires historicizing movement media-making to learn how such practices have long been used to challenge the monopoly over communication wielded by states and capitalism. In the literature, social movement media have been defined as the "outward-directed" practices by movement actors that engage publics through mass media and the 
"inward-directed" practices of movement media-making that mobilize movement actors (Rucht, 2004, p. 32). Critical scholars researching the Arab uprisings and subsequent movements have documented online and offline media strategies, noting that effective movement media-making embraces a diversity of media practices that are typically participatory and seek to amplify action for both inward and outward audiences (Costanza-Chock, 2014; Gerbaudo, 2012). Researching contemporary movement media practices, including media activism during and since the Arab uprisings, requires historicizing the diverse ways in which social movement actors used the Internet long before the development of blogging or other forms of social media.

For example, the first "social netwar" took place in the early 1990s, as stated in a report contracted by the US military (Ronfeldt et al., 1998). On January 1, 1994, Mayan indigenous guerrillas known as the Zapatistas took over the capital of Chiapas along with five other towns in southern Mexico to resist colonization and capitalist globalization, specifically the North American Free Trade Agreement, which the government of Mexico had endorsed without the consent of the indigenous population. The Zapatistas coordinated with media activists, who circulated the manifesto The First Declaration from the Lacandon Jungle over email, listservs, and online forums, sending the message around the world and effectively breaking the silence of hegemonic media in Mexico and international news media that had previously ignored the indigenous peoples' concerns about NAFTA (Padgett, 2017). The results were tangible: local and international media covered the Zapatistas' armed uprising, protestors pressured the government to negotiate, and a truce was signed by January 12, 1994 (Halkin, 2008). Since then, along with guns, the media became part of the Zapatistas' "arsenal" (p. 161).

Yet, the international media and colonial media in Mexico continued to neglect the Zapatistas' narrative. In late 1997, paramilitary forces trained and deployed by the Mexican government massacred nearly 50 indigenous people, mostly women and children, in the village of Acteal which was aligned with the Zapatistas. Local and international media reported the government's narrative that the murders resulted from inter-community conflict, thereby absolving the Mexican authorities of any complicity (Halkin, 2008). Such coverage motivated the Zapatistas to create their movement media for both inward and outward audiences. By 1998, the Chiapas Media Project began building regional media centers within Zapatista communities to produce and circulate multimedia content (Halkin, 2008).

Long before social media and two decades before the Arab uprisings, the Zapatistas recognized the need for networked and independent media as a necessary tool to be able to resist state power, capitalism, and colonialism effectively. Subcomandante Marcos detailed the media strategy of the Zapatistas. He said:
In August 1996, we called for the creation of a network of independent media, a network of information. We mean a network to resist the power of the lie that sells us this war that we call the Fourth World War. We need this network not only as a tool for our social movements but for our lives: this is a project of life, of humanity, humanity which has a right to critical and truthful information. (Indymedia, 2017, para. 1)

According to the Zapatistas, such a network was needed, not just in Chiapas, but as a global resource for social movements.

The social movement media strategy of the Zapatistas and the call for the creation of a network of independent media communicated by Subcomandante Marcos inspired media activist projects around the globe. In 1999, the Independent Media Center was established in a storefront in Seattle to share social movement media coverage of the World Trade Organization protests through an open-source website built for activist-produced multimedia content. At the time, media and technology activists behind the Independent Media Center's social movement media infrastructure did not know they were creating "the building blocks of the modern web: content management systems, blogs, and user-generated content" (Indymedia, 2017, para. 13). Within a few years, the Indymedia model spread like wildfire, establishing over 100 "open publishing" websites launched in more than 70 countries, some of which also opened local media centers, including in Palestine and Lebanon (Indymedia, 2017). Open publishing at Indymedia was not just for tech-savvy activists, but rather the platform enabled users with minimal computer skills to click a few buttons and contribute to their movement's media-making. Indymedia effectively mobilized new social movement media technology, but the Independent Media Center's open publishing architecture would later be commodified by capitalist social media (Costanza-Chock, 2014; Indymedia, 2017). Such media history, told from the point of view of social movement actors, is necessary to contextualize contemporary media activism.

This article asks: How does historicizing movement media-making help to understand the present as well as consider the future constraints and opportunities for social movement media in the MENA region? To answer this research question, this article mobilizes a political economy of communication framework to historicize social movement media practices from Chiapas to Palestine before and beyond the Arab uprisings. Unlike Tunisia and Egypt, Palestine did not witness mass mobilizations in public spaces during the 2010-2011 wave of popular protests. However, this article argues that analyzing social movement media within the long history of resistance in Palestine to colonial militaries and state power can benefit research on media and the Arab uprisings from the early 2010s, as well as future mobilizations in the MENA region. Mosco (2009) observed that a "good" political economy approach 
within communication research requires "an historical dimension" (p. 110). Sakr (2011) suggested that a political economy approach to historization within Arab cultural studies can help identify "the unequal distribution of communicative resources" (p. 227). Concerning scholarship on media in the MENA region, Khiabany (2011) also noted that a political economy approach critiquing Eurocentrism and global capitalism is necessary for the move towards de-Westernizing communication studies. Thus, this article challenges Western "normative liberal frameworks" in media research (Rodny-Gumede, 2020, p. 1) by developing a critical political economy framework to historicize social movement media with attention to capitalism, colonialism, and imperialism.

This framework will then be used to draw insight from scholarly and grey literature gathered about social movement media practices from Chiapas to Palestine and beyond. Additional data analyzed for this article include journalistic interviews conducted during the Fall of 2020 with Palestinian media activists as part of a podcast on media and Palestine, as well as the archive of an international workshop held in Salvador, Brazil, during the 2018 World Forum of Free Media, about the Radio Free Palestine project. To investigate the current context, further open-access information was collected from websites and social media accounts of Palestinian social movement media and media activists during April-May 2021. Analyzing these data within a political economy of communication framework seeks to transcend the narrow Arab uprisings moment and promote South to South learning by drawing lessons from the social movement media practices of indigenous peoples from Chiapas to Palestine. With this approach, this article aims to gain insight into the challenges and opportunities for media activists today working in the Arab region and beyond who are building new platforms, practices, and networks that resist state power, capitalism, and colonialism.

\section{Palestine and the 2010-2011 Arab Uprisings}

Under both the Ottoman and British authorities, Palestinians organized for independence and selfdetermination. When the League of Nations imposed the British Mandate over historic Palestine in 1922, four centuries of Ottoman rule ended. Later, in 1947, when the United Nations General Assembly passed Resolution 181 (II), the non-binding motion was opposed by Palestinians because it suggested that Jews, who were one-third of the population, could carve a "Jewish state" on $60 \%$ of the land. After the British withdrawal, Zionist militias attacked the largely unarmed Palestinians, and by May 15, 1948, more than 700,000 Palestinians (half the indigenous population) were ethnically purged from the land, and Israel declared itself a state in control of $78 \%$ of historic Palestine. This date has since been commemorated by Palestinians as the Nakba or catastrophe (Abdo-Zubi \& Masalha, 2018; Khalidi, 2020; Pappe, 2006). Today, Palestinians make up the world's largest refugee population, with the majority living inside historic Palestine or in neighboring countries (United Nations Relief and Works Agency, 2019). This article's focus on Palestine addresses a gap in existing media studies on the Arab uprisings that overlooks the rich history of revolutions and uprisings in Palestine.

In addition, some saw in the revolts of 2010-2011 that took a stand against state power and repression a reflection of the resistance and steadfastness (or sumoud) of the Palestinian Intifadas (Farsakh, 2012), and others describe the Intifadas as a pre-cursor to the MENA popular uprisings (Aouragh, 2012a). Inside Palestine, the uprisings in Tunisia and Egypt inspired the March 15 youth movement to mobilize under the slogan "The People Want the End of Divisions" (El-Sakka, 2016, p. 88). Youth-led protests in Palestine were followed by an agreement between Fatah and Hamas to reconcile differences, and later, the Nakba anniversary demonstrations held on May 15, 2011, saw protestors mobilize from the Occupied Territories, Lebanon, Jordan, Syria, and Egypt to the Israeli borders and checkpoints (El-Sakka, 2016). Concerning the resonance of the Arab uprisings in Palestine, al-Masri (2011, para. 3) asserted that the "impact will multiply since Palestine, the land of revolutions and uprisings for more than 130 years, cannot be immune to this spirit." Observing that Palestinians have continuously engaged in movement media-making in response to colonialism and imperialism as well as part of protesting the failed strategies of Palestinian political and economic elites, scholars interested in social movement media in the Arab region should also look to Palestine.

Scholars such as Khalidi, reflecting on the uprisings, also note that despite Arab public opinion overwhelmingly being in support of Palestine and against normalization with the "apartheid regime" in Israel (Robbins, 2020; United Nations Economic and Social Commission for Western Asia, 2017), the normalizing positions of some states in the region that pre-dated the 2010-2011 uprisings have become emboldened in the aftermath. He said, "The outcomes of the uprisings have made the status quo relations come out" (Jadaliyya, 2021). Khalidi noted the example of Raytheon, an Israeli company that is working with Arab states across the region and which built the missile defense system over Abu Dhabi, a partnership that began in 2006 (Jadaliyya, 2021; Raytheon, 2015). He offers an important assessment on the outcome of the uprisings for democracy in Palestine, illustrating that the work of the uprisings and social movement media in the region is unfinished or in the words of Khalidi, "This is not the end of the story, the march of democracy continues" (Jadaliyya, 2021).

Finally, in April 2021, "Ramadan Intifada" was in the headlines (again), and \#JerusalemUprising was trending on Twitter. After weeks of increasing Israeli military and settler attacks on Palestinian worshippers during Easter and Ramadan as well as on Palestinian protestors resisting expulsion from their homes in Jerusalem, on May 10, rockets were launched from the Gaza Strip and Israel 
bombarded the blockaded Gaza Strip with airstrikes that subsequently killed over 100 civilians including 66 children (United Nations Office for the Coordination of Humanitarian Affairs-Occupied Palestinian Territory, 2021). In response, on May 18, 2021, a general strike was organized across Palestine and the Dignity and Hope Manifesto of the so-called Unity Intifada circulated, calling for the "reunification" of Palestinian society to have a common "political will and means of struggle in the face of Zionism, in all of Palestine" (Mondoweiss, 2021, para. 4). A ceasefire ending the escalation was announced on May 21, 2021. Drawing on this moment for data collection helps to analyze the constraints and opportunities for social movement media using the political economy framework for social movement media developed in the next section.

\section{Precizing a Political Economy of Social Movement Media}

This article uses the lens of political economy of communication to historicize social movement media from Chiapas to Palestine. Within political economy studies of media, much of the literature focuses on hegemonic media and not on social movement media. Just before the Arab uprisings, Downing published an edited volume offering an Encyclopedia of Social Movement Media (2010) to document the "dizzying variety" and to fill the gap in social movement media research created by a Eurocentric orientation towards the global North (p. xxv). Afterwards, in a 2012 lecture to scholar-activists, Downing called for a political economy approach to study social movement media that should investigate "not only how to dissect the dynamics of global capital and the state, but equally to understand social movement media projects as potential agents of a democratically generated critical political economy and critical cultural analysis" (2013, p. 23). Taking up Downing's call, this section develops a political economy framework to historicize social movement media practices in Palestine and to provide a critical reflection on the use of media for revolution before and beyond the Arab uprisings.

Briefly, the study of political economy of communication draws on Marxist theories and analysis techniques to examine how capitalism shapes political and economic contexts that impact media institutions, production practices, and the experiences of users or audiences, focusing on the implications for social relations, culture, and power (Fuchs, 2016). Where political economy of communication scholars typically investigate the economic practices of hegemonic media and the ideologies they communicate, the political economy of social movement media is understudied. Researchers studying social movement media practices in Canada (Jeppesen, 2018; Jeppesen \& Petrick, 2018) used a feminist political economy framework to investigate how autonomous media projects challenge capitalistic hegemonic media practices by organizing alternative or social economies that mobilize material and immaterial resources in a variety of anti-capitalist ways. The alternative political economies documented by Jeppesen and Petrick among social movement media in North America include securing funds from users or audiences to remain independent of corporate or state funding agendas and providing labor by organizing media spaces as community-owned workers co-operatives or collectively-run (Jeppesen \& Petrick, 2018). More recently, Artz (2020) employed a political economy framework to study "ownership production practices content for social use" (p. 1391) among social movement media in Venezuela. Conducting political economy of communication research within the "socialist-leaning" state, Artz argued that social movements had produced a "parallel political economy of public, community media" (p. 1393). He observed media laws that affirm communication rights, including "active participation and oversight of citizens in all the processes of production, distribution, and consumption of media messages" (Artz, 2020, p. 1391, from the Venezuelan National Assembly 2004 Law on Social Responsibility of Radio and Television). As a result, the state licensed and resourced almost 1,200 community-based radio and television production and broadcasting studios by 2011, providing widespread public access to communitycontrolled media that challenge hegemonic media practices by broadcasting revolutionary content.

Scholars working in the MENA region have observed that the political economy of media is influenced not only by capitalism but also colonialism and imperialism. Since the 1970s-1980s, political economy scholars have studied how colonialism and imperialism shape media ownership, production, distribution, and reception (Mattelart, 1979; Smythe, 1981). Few media scholars researching the MENA region or the Arab uprisings use a political economy of communication approach to study the influence of colonialism and imperialism. Aouragh and Chakravartty (2016) observed that despite imperialist wars in South Asia and the MENA region, the field of media studies suffers from "a visible dearth in scholarship and discussion on the topic of US Empire or issues of empire" (p. 561). The authors call for a return to studies of empire, especially after the Arab uprisings, which unmasked the complicity of telecommunications and social media companies in following "military regimes or US imperial interests" (p. 565).

A sub-field of political economy in media studies has examined the beneficial role of communication companies in war as well as the historical relationship between media and the military, which Schiller (1969) coined as the "military-industrial communications complex." Studying internet use in Palestine and in the diaspora, Aouragh $(2011,2016)$ used political economy of communication frameworks to investigate how Israeli military practices shape online and offline activism. She observed that Palestinian activism online is structured by the military-industrial communications complex that benefits technology companies and Israel, sparking a "cyber 
Intifada" that includes a diversity of tactics Palestinian use to engage technology as "an integral part of political activism" (2016, p. 137). Based on her research of internet activism in Palestine as well as across the MENA region, Aouragh concluded that the political economy of media "in the MENA region often comes down to colonialism and imperialism" (2012b, p. 527). In Tawil-Souri and Aouragh's (2014) research of Palestinian online activism, the authors draw on a political economy approach to analyze how the Israeli military and global capitalism (through "cyber-colonialism") affect both the Internet and offline/online activism in Palestine (p. 116). Concerning social media in Palestine, Kuntsman and Stein (2015) documented the "digital militarism" of Israel whereby social media platforms are used as tools of war. This work illustrates the need for a political economy approach that analyses how the military-industrial communications complex, underpinned by capitalism, colonialism, and imperialism, shapes social movement media in Palestine. Such an approach builds on Downing's wish for scholars to document the history of diverse media practices deployed by social movement actors in resistance to hegemonic media practices and to investigate the local contexts determined by state and corporate (including media and technology companies) surveillance and enforcement practices (2013, pp. 24-27).

Advancing the above literature, this article historicizes social movement media from Chiapas to Palestine before and beyond the 2010-2011 Arab uprisings using a political economy approach. Where the study of the political economy of communication generally focuses on how capitalism shapes media, research mobilizing a political economy lens in the MENA region should also historicize the impact of colonialism and imperialism on social movement media practices. Within the literature reviewed above, scholars documented media strategies that facilitate alternative political economy practices (i.e., mobilizing resources guided by anti-capitalist or revolutionary socialist politics) and embrace a diversity of tactics (i.e., circulating media using digital or legacy or multimedia platforms, building community-run production facilities, etc.). The next section uses a political economy framework to provide a case study of movement media-making by historicizing the ownership, production, and content practices in Palestine. By doing so it shows how social movement media practitioners use specific media strategies that produce alternative political economies through the use of diverse media tactics for both inward and outward audiences. Such actions resist the military-industrial communications complex which is shaped by capitalism, colonialism, and imperialism, including state and corporate surveillance and enforcement practices.

\section{Historicizing Social Movement Media from Chiapas to Palestine}

The following case study of movement media-making from Palestine also draws on examples from Chiapas and beyond using a political economy of communication framework for historicizing social movement media with three goals. The first aim seeks to investigate social movement media strategies (i.e., ownership, production, and content practices) mobilized over time, the second goal will analyze how movement media-making also produces alternative political economies, and the final objective will consider how social movement media practices resist the military-industrial communications complex. The data used for this case study draws together scholarship, grey literature, and practitioner knowledge, the latter of which includes interviews with Palestinian media activists.

\subsection{A Brief History of Social Movement Media in Palestine}

The history of Palestinian social movement media predates the Nakba. Since the printing press arrived in Palestine in the early 1900s, the indigenous population has used every communication medium as a tool for amplifying resistance to dispossession, genocide, and occupation (King, 2021b). Throughout the 1930s, Palestinian revolutionaries published newspapers to circulate information about the struggle for national liberation and support actions for self-determination against British colonial rule, including running articles calling for general strikes and reporting on revolts (Omer, 2015). After seeing newspapers shut down in Palestine by the British during the First World War, Palestinians also turned to small-scale broadcasting through radio stations like Sawt Al-Falestin which broadcast in resistance to radio programming from British authorities (such as the BBC's Empire Service) and Zionist colonialists (Boyd, 1999). In Algeria, the use of radio by the Voice of Free Algeria was similarly part of the tools of resistance used to challenge the French occupation, as documented by Fanon (1994). The Zapatistas' Radio Insurgente also enabled the peoples of Chiapas to hear programming produced by indigenous people and in their languages for the first time (Costanza-Chock, 2014), much like the experience in Algeria and Palestine.

During the Nakba in 1948, Zionist militias occupied communication infrastructure and destroyed the media sector of Palestine, taking over radio stations, shutting down newspapers, and expelling journalists (King, 2021b). Afterward, Palestinians in the diaspora used radio and television during the 1950s-1980s to broadcast social movement media across the borders erected by the Israeli military (Bishara, 2009). Throughout the First Intifada, when newspapers were heavily censored by the Israeli military, students and youth organizers in Palestine resorted to graffiti and fliers to complement the radio and television broadcasts coming from the resistance in the diaspora (Bishara, 2009). Reflecting on the First Intifada, the Palestinian journalist and media activist Daoud Kuttab recalls that "Palestinians watched news. We never made news." At that time, he added, 
television broadcasting produced inside of Palestine was made by Israeli media or the foreign press. Kuttab organized television trainings at the Institute of Modern Media based at Al-Quds University and, in 1993, produced the first experimental TV broadcasts presented by Palestinians inside Palestine (Kuttab, 2020). The Oslo Accords began shortly after and resulted in tangible communication gains for Palestinians inside of the Occupied Territories, including granting rights to the Palestinian Authority to issue licenses for radio and television broadcasting as well as access to spectrum for Internet use (King, 2021b). The subsequent development of the media system in the Occupied Territories was rapid, and social movement media benefited from these developments. By the start of the Second Intifada, Palestinian media activists had better access to mobile phones and the Internet, but these tools did not replace their use of legacy media. Rather, Palestinians still produced reports for radio and television while using the Internet to distribute this content across the globe.

\subsection{Embracing a Diversity of Tactics}

Further exploring this broad history requires investigating media strategies (i.e., ownership, production, and content practices) within a specific social movement media organization in Palestine. During the Second Intifada, the International Middle East Media Center (IMEMC, www.imemc.org) was founded in Beit Sahour, near Bethlehem in the West Bank, by Palestinian media activists who were part of the International Solidarity Movement (ISM). As a Palestinian-led direct action movement, the ISM began in 2001 to bring activists from around the world to promote and support nonviolent action in the West Bank and Gaza Strip. The IMEMC was officially organized as a project of the Palestinian Centre for Rapprochement, a non-governmental organization registered in 1988 that spearheaded nonviolent resistance in Palestine throughout the First Intifada, including the 1989 tax strike called under the slogan "No Taxation Without Representation" (Palestinian Centre for Rapprochement, 2020). Today, the IMEMC remains a non-registered organization and continues to exist as a project of the Palestinian Centre for Rapprochement. Thus, the project is owned by its team made up of volunteers and a small staff who take decisions together. This ownership model contrasts with hegemonic media in Palestine that are typically owned by the state, political parties, or private companies and run hierarchically (CEO, editor-in-chief, etc.).

Journalist and activist George Rishmawi was part of founding the ISM and after the IMEMC. He explains why the IMEMC was created:

Through our activities in the ISM, where international peace activists were present in several locations in the West Bank and Gaza Strip, we noticed that many of the news and events, especially by Israeli settlers, do not get reported anywhere in the international media. Therefore, we used the fact that we have people on the ground there who can report in English, so they started taking photos and sending us news updates. That was in 2002 before starting IMEMC. At that point, we created Pal Media Alert or Palestine Media Alert... a simple website just to post the information. Then when we saw this is really needed, very important, and provides a good deal of information that people do not ever get on their news outlets, we thought this needs to become a professional news service. So we decided in 2003 to start the IMEMC. (Rishmawi, 2020)

The IMEMC quickly expanded from posting alerts to circulating news online in multiple media formats, including text, video, and audio reports, the latter of which were broadcast by radio stations in the diaspora. The initial production practices of the IMEMC aimed to bring together Palestinians and international volunteers who would collaborate to produce reports in English. When the volunteer base of the IMEMC expanded, reports in Spanish were added. Similarly, the Zapatistas also connected with audiences globally through shortwave radio broadcasts in Spanish and archived audio content on its website (Radio Insurgente, 2017).

Not only did the media circulated by IMEMC seek to amplify the actions of the ISM for both inward and outward audiences, but the IMEMC's reporting also sought to fill a gap in the international media produced from Palestine that silenced the Palestinian narrative. To ensure IMEMC content depicted the Palestinian narrative, a "journalist handbook" was created as a manual for volunteers producing content for the IMEMC. Rishmawi explained that the handbook includes content standards, such as preferred terms to ensure the Palestinian narrative is centered in IMEMC reports:

At the IMEMC, you will notice we use the term abduct. We use it to replace the term arrest. Because in the US or in Canada or in Europe, when they read "arrest," what they have in mind is a police force, maybe a police officer would stop somebody, read them their rights, arrest them, and they will have a lawyer, etc. But what happens in Palestine is different; it is the military and not the police. The military go from one area to another area that has civilians from a different country and just takes them and puts them somewhere in an unknown destination. This is an abduction or a kidnapping, to be more precise. So we avoid the term "arrest" and use "abduction" or "kidnapping" so people will have a closer image of actually what happens on the ground. (Rishmawi, 2020)

The IMEMC, as an example of social movement media, maintains content practices and policies that focus, according to Rishmawi, on telling "the other side of the story" (Rishmawi, 2020). 
Similar to the media strategy of the Zapatistas that aimed to break the silencing of indigenous peoples and network social movements worldwide, the IMEMC was founded to report news from the Palestinian perspective and sought to connect media activists worldwide with the nonviolent resistance movement inside Palestine. In 2008, the IMEMC expanded this network and connected with community radio stations, social movements, and media activists across several continents to produce Radio Free Palestine, initiated as an 18-hour collaborative radio broadcast held on May 15 to commemorate the 60th anniversary of the Nakba. Radio Free Palestine was launched to expand the few broadcasting spaces for the Palestinian narrative in the diaspora by filling the void with a marathon of non-stop radio programming in Arabic, English, Spanish, and French about the Nakba and news from the annual commemorative demonstrations held in Palestine (Marouf, 2018). Radio Free Palestine continues as a 24-hour broadcast, last collaboratively produced and hosted in 2019 by radio stations across Asia, Africa, Europe, and North America. The content practices of Radio Free Palestine mirror the production practices initiated by the IMEMC that invite internationals to join Palestinians in making media that centers on the Palestinian narrative and amplifies social movements for Palestinian human rights.

\subsection{Mobilising Alternative Political Economies}

De-development in Palestine has constrained the economy (including the media economy), and a large majority of households live below the poverty line, resulting in projects (media and non-media) in Palestine having to rely on funding from international sources (Turner \& Shweiki, 2014). As a project that spans nearly twenty years, the IMEMC remains active because it relies predominately on volunteer labor. As such, the IMEMC has not been challenged by the NGO-ization of social movements in Palestine, whereby social movement agendas become projects run by a "professional elite for the purpose of accountability vis-à-vis foreign donors" (Jad, 2008 , p. 2), or the professionalization of social movement media as documented by Costanza-Chock (2014). Both the Chiapas Media Project and Indymedia have resisted the agendas of donors, the former creating a policy to "apply for grants as long as there were no strings attached and no political agenda of the foundation that conflicted with our/the community's agenda" (Halkin, 2008, p. 70) and the latter rejecting a $\$ 50,000$ grant from the Ford Foundation for similar reasons collectively deliberated (Jeppesen \& Petrick, 2018).

Rishmawi explains that the IMEMC works with "minimal resources." He said:

One of the main challenges is financial resources....It is still functioning because we are running with minimum budget. A great deal of volunteerism in this project is what is keeping this project running for the last 17 years otherwise we would have shut down. We had to shut down the audio reports "Palestine Today" and "This Week in Palestine" for lack of financial resources. We don't sell any information; we don't get any money in exchange of the news that we provide. We want it to be free, we want it to be available for everyone. (Rishmawi, 2020)

The IMEMC is circulating social movement media free of charge, yet they do not seek donations from users. The IMEMC does receive a small annual donation (with zero obligations) from If Americans Knew, a charitable research organization based in the US, that pays the salary of the one staff member that IMEMC has today (Rishmawi, 2020). Other social movement media in Palestine do accept donations from users, like the popular Quds News Network founded by youth activists in 2012 that distributes movement media content in Arabic and English on its website and across social media, but Quds News Network only accepts donations that have no conditions from the donor (Quds News Network, 2021). Rishmawi (2020) noted that at the IMEMC:

Nobody ever asked us to remove anything, and if they did, I don't think we would. One of the good things of not having funding is that you have no donor or funder to force you to do anything. So this is one of the difficulties, but this has its positive sides, which is that you are also free, fully independent, and nobody can dictate to you what to write, what to say, what to have there or what to remove.

The internal policies and decisions of social movement media reflect alternative political economies that resist capitalism, colonialism, and imperialism. Donor funds may come with foreign or for-profit agendas that center on one issue (such as women's rights) over others (such as national liberation, see Jad, 2008). Costanza-Chock (2014) notes that donor funding often results in the professionalization of social movement media whereby "private foundations often push organic movement networks toward issue-based policy advocacy, professionalization, and clear brand identity, all of which require top-down communication strategies and tight control over messaging and framing" (p. 192). However, in Palestine, the alternative political economies of social movement media are primarily impacted by the Israeli military that restricts access to much-needed material and immaterial resources, for example, barring volunteers, media equipment, or even donations from crossing the borders and checkpoints (Rishmawi, 2020).

\subsection{Resisting the Military-Industrial Communications Complex}

Media, technology companies, and military forces comprising the military-industrial communications complex have had a beneficial relationship in Palestine since the 
British established the first radio station serving all of historic Palestine in 1936. Today, the Palestinian media system, from broadcasting to telecommunications, across historic Palestine is restricted by the Israeli military. For example, the Israeli military regularly targets Palestinian media workers and infrastructure, as was the case during the last bombardment of the Gaza Strip in May 2021 when Israel leveled more than a dozen media offices (Committee to Protect Journalists, 2021). Social movement media also face targeted attacks by the Israeli military. Rishmawi (2020) recalled a raid on the offices of the IMEMC: "Once the Israeli forces invaded our office and took all of our equipment and computers in May 2003. This was mainly because of our involvement in ISM... and this was just after [ISM activist] Rachel Corrie was killed in Gaza" by the Israeli military. Not long after, the IMEMC began reaching thousands of website visitors per day, followed by continuous cyberattacks on IMEMC servers. In response, the IMEMC backs up its website across several servers (Rishmawi, 2020). To avoid paramilitary raids, the Zapatistas' Radio Insurgente broadcasts from secret locations across Chiapas (Woodman, 2018).

Social movement media in Palestine also face censorship online for using tools like social media. Unit 8200 is the largest battalion within the Israeli military that monitors the communication of Palestinians across all cellular and digital platforms (Tawil-Souri, 2017). A 2018 report revealed that social media platforms complied with $90 \%$ of requests from the Israeli military to censor Palestinian content (Human Rights Watch, 2021). More recently, Facebook appointed a former Israeli military censor to its oversight board (Nassar, 2020). In May 2021, more than 500 takedowns and censoring of Palestinian content were recorded across Instagram, Facebook, and Twitter (7amleh, 2021). The IMEMC's page on Facebook is currently threatened with suspension, and no information has been provided by Facebook as to why their page was flagged. According to Rishmawi (2020):

Facebook says we are violating "community standards" and one of our volunteers has communicated with Facebook, and they have failed to give one clear reason of how IMEMC violated any community standard. So, for now, the Facebook page is still flagged, and we are trying to remove the flag. I think this is part of the pressure that we are having at IMEMC.

Quds News Network has also faced censorship on Twitter when all of their verified accounts with almost a million followers were suspended without explanation for nearly two years. Quds News Network's accounts have since been restored on Twitter, but the news outlet maintains backup accounts for all its social media pages.

The military-industrial communications complex in Palestine is maintained by the Israeli military through beneficial relationships with US-based social media companies whose censorship policies are "fundamentally anti-Palestinian" (King, 2021a). Indeed, social media cen- sorship is the epitome of the military-industrial communications complex where corporate interests overlap with American imperialism and Zionist colonialism. Social movement media strategies in Palestine include finding new ways of resisting the military-industrial communications complex as evident during the Unity Intifada. Dashes masking words started appearing in social media posts in English and Arabic, the latter of which also appeared without vowel markings. Additionally, a campaign was organized to protest against censorship on Facebook and Instagram (also owned by Facebook) by targeting the former with one-star reviews in the Apple App and Google Play stores, sinking the platform's ratings (Lyons, 2021). These are some of the resistance strategies, along with the diverse tactics reviewed above concerning ownership, production, and content practices of social movement media in Palestine and beyond, that are generating alternative political economies and effectively opposing the militaryindustrial communications complex.

\section{Learning from Social Movement Media}

Historicizing movement media-making using a political economy framework, as represented by Table 1, can help to understand the present strategies as well as to consider the future constraints and opportunities for social movement media in the MENA region. Where social movement media in the MENA region often uses global communication resources such as radio and Internet platforms, historicizing affords media activists and researchers the opportunity to learn movement media-making strategies from across borders. Importantly, Artz notes that the revolution in Venezuela resulted in over a thousand community-run TV and radio facilities, adding "revolutions everywhere can learn from precedents. Each revolutionary struggle also can contribute further lessons" (2020, p. 1403).

However, social movement media is challenged by memory. This is because when projects are no longer sustainable, websites, archives, training tools, and collective histories of movement media-making disappear. Additional research is needed to historicize social movement media, but also to learn with movement media practitioners in ways that benefit future media activists. Diraya (2020) is one such platform that provides case studies of media activist practices across the MENA region, including the IMEMC, and offers media literacy resources that build on these practices. Studying the military-industrial communications complex structured by capitalism, colonialism, and imperialism requires learning from the long and global history of revolutionary media struggle, from Chiapas to Palestine, about the many alternative political economies and diversity of tactics used to break through the silence imposed by hegemonic media. 
Table 1. Strategies of social movement media from Chiapas to Palestine.

\begin{tabular}{lll}
\hline Political Economy Framework & Chiapas & Palestine \\
\hline Historicizing social movement media & $\begin{array}{l}\text { Communiques from EZLN circulated } \\
\text { online by media activists in the 1990s, } \\
\text { followed by EZLN beginning radio } \\
\text { broadcasting and video production in } \\
\text { the 2000s, also using shortwave radio } \\
\text { and the Internet to share this content } \\
\text { worldwide. }\end{array}$ & $\begin{array}{l}\text { Palestinian newspapers began } \\
\text { circulating in 1908 and radio began } \\
\text { broadcasting by the 1930s, television } \\
\text { and radio from diaspora aired }\end{array}$ \\
& & throughout the 1950s-80s, followed \\
& & $\begin{array}{l}\text { Intifada, and launching radio and } \\
\text { television from Palestine in the 2000s } \\
\text { and using the Internet to share news } \\
\text { and content globally. }\end{array}$
\end{tabular}

Diversity of tactics

Alternative political economies

Military-industrial communications complex
Multimedia, multiplatform, community-run spaces, content guidelines to center indigenous narratives, indigenous-international networks among audiences and media activists

Minimal resources, volunteer power, free from donor or funder agendas

Backup servers and accounts, masking words in social media content, production and broadcasting facilities in secret locations

\section{Acknowledgments}

This article was made possible with research assistance from Christina Cavalcanti. Data was made available, in part, through the Media and Palestine course podcast that was co-produced with Master's students studying multimedia journalism at Lebanese American University, including Dalia Attar, Jana El Amine, Rayan Haidar, Ghiwa Haidar Ahmad, Ahmad Karakira, Hussein Kassab, Ayman Lezzeik, Raghda Mugharbil, Fatima Takash, and Yara Yatim.

\section{Conflict of Interests}

The author declares no conflict of interest.

\section{Disclaimer}

The Arab-German Young Academy of Sciences and Humanities (AGYA) is supporting the thematic issue "Ten Years after the Arab Uprisings: Beyond Media and Liberation," edited by AGYA alumna Hanan Badr (Gulf University of Science and Technology, Kuwait) and AGYA member Lena-Maria Möller (Max Planck Institute for Comparative and International Private Law, Germany). AGYA is funded by the German Federal Ministry of Education and Research (BMBF). The authors remain solely responsible for the content and recommendations provided in this publication, which do not reflect the positions of AGYA or any of its funding partners.

\section{References}

7amleh. (2021, May 21). The attacks on Palestinian digital rights. https://7amleh.org/2021/05/21/7amleh- issues-report-documenting-the-attacks-onpalestinian-digital-rights

Abdo-Zubi, N., \& Masalha, N. (2018). An oral history of the Palestinian Nakba. Zed Books.

al-Masri, H. (2011). Achieving a Palestinian spring. Al-Shabaka: The Palestinian Policy Network. https:// al-shabaka.org/roundtables/achieving-palestinianspring

Aouragh, M. (2011). Palestine online: Transnationalism, the Internet and the construction of identity. I.B. Tauris.

Aouragh, M. (2012a). Framing the Internet in the Arab revolutions: Myth meets modernity. Cinema Journal, 52(1), 148-156. https://www.jstor.org/stable/ 23360288

Aouragh, M. (2012b). Social media, mediation and the Arab revolutions. tripleC: Communication, Capitalism \& Critique, 10(2), 518-536. https://doi.org/ 10.31269/triplec.v10i2.416

Aouragh, M. (2016). Revolutionary manoeuvrings: Palestinian activism between cybercide, and cyber intifada. In L. Jayyusi \& A. S. Roald (Eds.), Media and political contestation in the contemporary Arab world (pp. 129-160). Palgrave Macmillan.

Aouragh, M., \& Chakravartty, P. (2016). Infrastructures of empire: Towards a critical geopolitics of media and information studies. Media, Culture \& Society, 38(4), 559-575. https://doi.org/10.1177/ 0163443716643007

Armbrust, W. (2012). A history of new media in the Arab Middle East. Journal for Cultural Research, 16(2/3), 155-174. https://doi.org/10.1080/14797585.2012. 647666

Artz, L. (2020). A political economy for social movements and revolution: Popular media access, power and cultural hegemony. Third World Quar- 
terly, 41(8), 1388-1405. https://doi.org/10.1080/ 01436597.2019 .1668265

Bishara, A. (2009). New media and political change: The case of the two Palestinian Intifadas (Working Paper, EUI RSCAS, 2009/21, Mediterranean Programme Series). http://hdl.handle.net/1814/11487

Boyd, D. A. (1999). Broadcasting in the Arab world: A survey of the electronic media in the Middle East (3rd ed.). lowa State University Press.

Committee to Protect Journalists. (2021, May 13). Israeli air strikes destroy buildings housing more than a dozen media outlets in Gaza. https://cpj.org/2021/ 05/Israeli-air-strikes-destroy-buildings-housingmore-than-a-dozen-media-outlets-in-gaza

Costanza-Chock, S. (2014). Out of the shadows, into the streets! Transmedia organizing and the immigrant rights movement. MIT Press.

Diraya. (2020). Media literacy for tomorrow: Leaning with MENA media activists. https://www.diraya. media

Downing, J. D. (2013). Towards a political economy of social movement media. Democratic Communique, 26(1), 17-28. https://journals.flvc.org/demcom/ article/view/83389

Downing, J. D. (Ed.). (2010). Encyclopedia of social movement media. SAGE.

El-Sakka, A. (2016). Palestinian youth social movement's protesters. In S. Schaar \& M. E. Ahmadi (Eds.), The birth of the Arab citizen and the changing Middle East (pp. 82-99). Olive Branch Press.

Fanon, F. (1994). This is the voice of Algeria. In F. Fanon (Ed.), A dying colonialism (pp. 69-98). Grove Press.

Farsakh, L. (2012, February 21). Searching for the Arab spring in Ramallah. Jadaliyya. https://www.jadaliyya. com/Details/25295/Searching-for-the-Arab-Springin-Ramallah

Fuchs, C. (2016). Reading Marx in the information age: A media and communication studies perspective on capital. Routledge.

Gerbaudo, P. (2012). Tweets and the streets: Social media and contemporary activism. Pluto Press.

Halkin, A. (2008). Outside the indigenous lens: Zapatistas and autonomous videomaking. In P. Wilson \& M. Stewart (Ed.), Global Indigenous Media (pp. 160-180). Duke University Press.

Human Rights Watch. (2021, October 8). Israel/Palestine: Facebook censors discussion of rights issues. https:// www.hrw.org/news/2021/10/08/israel/palestinefacebook-censors-discussion-rights-issues

Indymedia. (2017, January 1). Holding out for unalienated communication. Briarpatch Magazine. https://briarpatchmagazine.com/articles/view/ holding-out-for-un-alienated-communication

Jad, I. (2008). The demobilization of women's movements: The case of Palestine. Association for Women's Rights in Development. https://www.awid. org/publications/changing-their-world-conceptsand-practices-womens-movements
Jadaliyya. (2021, January 27). Reflections on mass protests \& uprisings in the Arab world [Part 1 and 2 Videos]. https://www.jadaliyya.com/Details/42316

Jeppesen, S. (2018). Digital movements: Challenging contradictions in intersectional media and social movements. Communicative Figurations (Working Paper, No. 21). https://www.uni-bremen.de/ fileadmin/user_upload/fachbereiche/fb9/zemki/ media/photos/publikationen/working-papers/ 2018/CoFi_EWP_No-21_Jeppesen.pdf

Jeppesen, S., \& Petrick, K. (2018). Toward an intersectional political economy of autonomous media resources. Interface, 10(1/2), 8-37. http://www. interfacejournal.net/wordpress/wp-content/ uploads/2018/12/Interface-10-1-2-JeppesenPetrick.pdf

Khalidi, R. (2020). The hundred years' war on Palestine: A history of settler colonialism and resistance, 1917-2017. Metropolitan Henry Holt.

Khiabany, G. (2011). Whither Eurocentrism? Media, culture and nativism in our time. In G. Wang (Ed.), De-Westernizing communication research: Altering questions and changing frameworks (pp. 207-221). Routledge.

King, G. (2021a). Breaking the silence: Public communication in/for Palestine. Media and Development, 3, 36-38. https://waccglobal.org/breaking-the-silencepublic-communication-in-for-palestine

King, G. (2021b). Palestine: Resilient media practices for national liberation. In C. Richter \& C. Kozman (Eds.), Arab media systems (pp. 37-54). Open Book Publishers. https://books.openbookpublishers.com/ 10.11647/obp.0238/ch3.xhtml

Kuntsman, A., \& Stein, R. L. (2015). Digital militarism' Israel's occupation in the social media age. Stanford University Press.

Kuttab, D. (2020). Week 4-Mr. Daoud Kuttab. JSC 688 media and Palestine course podcast [Audio podcast]. https://archive.org/details/jsc-688-podcast

Lyons, K. (2021, May 23). Facebook reportedly hit with campaign by pro-Palestinian activists leaving 1-star app store ratings. The Verge. https://www. theverge.com/2021/5/23/22450319/facebookcampaign-pro-palestine-activists-1-star-app-storeratings-apple-google

Marouf, L. (2018). Radios associatives : Levier de démocratisation de l'information et de la communication en Afrique et au Machrek [Community radio: Raising the democratization of information and communication in Africa and the Magreb]. World Forum of Free Media, Salvador, Brazil.

Matar, D. (2012). Contextualising the media and the uprisings: A return to history. Middle East Journal of Culture and Communication, 5(1), 75-79. https:// doi.org/10.1163/187398612X624391

Mattelart, A. (1979). Multinational corporations and the control of culture: The ideological apparatuses of imperialism. Humanities Press. 
Mondoweiss. (2021). The manifesto of dignity and hope [Open Letter]. https://mondoweiss.net/2021/ 05/the-manifesto-of-dignity-and-hope

Mosco, V. (2009). The political economy of communication (2nd ed.). SAGE.

Nassar, T. (2020, May 26). Facebook appoints Israeli censor to oversight board. The Electronic Intifada. https://electronicintifada.net/blogs/tamara-nassar/ facebook-appoints-israeli-censor-oversight-board

Omer, M. (2015). Against all odds: Media survive in Palestine. Global Media Journal-African Edition, 9(2), 105-133. https://doi.org/10.5789/9-2-209

Padgett, R. (2017, February 25). Radical legacy of the Zapatista's media strategy. Intifada! http://www. svllywood.com/intifadaessays/radicalmedia

Palestinian Centre for Rapprochement. (2020). About PCR. https://pcr.ps/about-our-work

Pappe, I. (2006). The ethnic cleansing of Palestine. Oneworld.

Quds News Network. (2021). Man nahnu [Who are we] https://qudsn.net/page/3/\%D9\%85\%D9\%86-\%D9\% 86\%D8\%AD\%D9\%86

Radio Insurgente. (2017). Who are we? https://web. archive.org/web/20170315135557/http:// radioinsurgente.org/index.php?name=whoweare

Raytheon. (2015). Raytheon, Abu Dhabi Ship Building celebrate first decade of partnership [Press Release]. https://raytheon.mediaroom.com/2015-11-09-

Raytheon-Abu-Dhabi-Ship-Building-celebrate-firstdecade-of-partnership

Rishmawi, G. (2020). Week 8-Mr. George Rishmawi. JSC 688 media and Palestine course podcast [Audio podcast]. https://archive.org/details/jsc-688-podcast

Robbins, M. (2020, December 11). Taking Arabs' pulse on normalization of ties with Israel. Arab Barometer. https://www.arabbarometer.org/2020/12/takingarabs-pulse-on-normalizing-ties-with-israel

Rodny-Gumede, Y. (2020). Expanding comparative media systems analysis from transitional to postcolonial societies. International Communication Gazette, 82(7), 611-627. https://doi.org/10.1177/ 1748048519897515

Ronfeldt, D., Arquilla, J., Fuller, G., \& Fuller, M. (1998). The Zapatista "social netwar" in Mexico. RAND Corporation. https://www.rand.org/pubs/monograph_ reports/MR994.html

Rucht, D. (2004). The quadruple "A": Media strategies of protest movements since the 1960s. In W. Van De Donk, B. D. Loader, P. G. Nixon, \& D. Rucht (Eds.), Cyberprotest: New media, citizens and social movements (pp. 25-48). Routledge.

Sakr, N. (2011). Placing political economy in relation to cultural studies: Reflections on the case of cinema in Saudi Arabia. In T. Sabry (Ed.), Arab cultural studies: Mapping the field (pp. 214-233). I.B. Tauris.

Schiller, H. I. (1969). Mass communications and American empire. A.M. Kelley.

Smythe, D. W. (1981). Dependency road: Communications, capitalism, consciousness, and Canada. Praeger.

Tawil-Souri, H. (2017). Surveillance sublime: The security state in Jerusalem. Jerusalem Quarterly, 68, 56-65. https://www.palestine-studies.org/en/node/ 210944

Tawil-Souri, H., \& Aouragh, M. (2014). Intifada 3.0? Cyber colonialism and Palestinian resistance. The Arab Studies Journal, 22(1), 102-133. http://www.jstor.org/ stable/24877901

Turner, M., \& Shweiki, O. (2014). Decolonizing Palestinian political economy: De-development and beyond. Palgrave Macmillan.

United Nations Economic and Social Commission for Western Asia. (2017). Israeli practices toward the Palestinian people and the question of Apartheid. https://electronicintifada.net/sites/default/files/ 2017-03/un_apartheid_report_15_march_english_ final_.pdf

United Nations Office for the Coordination of Humanitarian Affairs-Occupied Palestinian Territory. (2021, May 23). Escalation in the Gaza Strip, the West Bank and Israel. https://www.ochaopt.org/content/ escalation-gaza-strip-west-bank-and-israel-flashupdate-12-covering-1200-21-may-1200-23-may

United Nations Relief and Works Agency. (2019). Occupied Palestinian territory emergency appeal 2019. https://www.unrwa.org/resources/emergencyappeals/occupied-palestinian-territory-emergencyappeal-2019

Woodman, S. (2018). From armed rebellion to radical radio: Nearly 25 years after they seized power in Chiapas, Mexico, Zapatistas are running village schools and radio stations, and even putting people up for election. Index on Censorship, 47(4), 73-75. https:// doi.org/10.1177/0306422018819354

\section{About the Author}

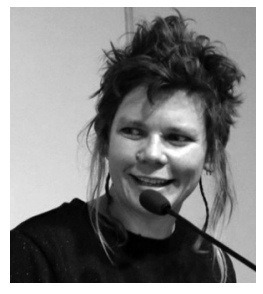

Gretchen King (PhD) is assistant professor of communication and multimedia journalism at the Lebanese American University in Beirut. She serves as the director of pedagogy and curriculum design at LAU's Institute of Media Research and Training. In her research, she focuses on alternative media and community radio in the regions of North America, North Africa, and West Asia. 